\title{
Coma Greater than 24 Hours
}

National Cancer Institute

\section{Source}

National Cancer Institute. Coma Greater than 24 Hours. NCI Thesaurus. Code C141239.

An indication that coma has lasted more than 24 hours. 